Revue bibliographique pour le domaine irano-aryen

\title{
Elizabeth Carter. "Parthian Pottery from Well 508 in the Ville Royale I Sounding at Susa"
}

\section{Leonardo Gregoratti}

\section{Q OpenEdition \\ 1 Journals}

\section{Electronic version}

URL: http://journals.openedition.org/abstractairanica/50221

DOI: 10.4000/abstractairanica. 50221

ISBN: 1961-960X

ISSN: 1961-960X

Publisher:

CNRS (UMR 7528 Mondes iraniens et indiens), Éditions de l'IFRI

Electronic reference

Leonardo Gregoratti, "Elizabeth Carter. "Parthian Pottery from Well 508 in the Ville Royale I Sounding at Susa"', Abstracta Iranica [Online], Volume 40-41 | 2019, document 56, Online since 30 December 2019, connection on 16 April 2021. URL: http://journals.openedition.org/abstractairanica/50221 ; DOI: https://doi.org/10.4000/abstractairanica.50221

This text was automatically generated on 16 April 2021.

Tous droits réservés 


\title{
Elizabeth Carter. "Parthian Pottery from Well 508 in the Ville Royale I Sounding at Susa"
}

\author{
Leonardo Gregoratti
}

\section{REFERENCES}

Elizabeth Carter. "Parthian Pottery from Well 508 in the Ville Royale I Sounding at Susa" in Sébastien Gondet, Ernie Haerinck (éds.). L'Orient est son jardin, hommage à Rémy Boucharlat. (Acta Iranica 58), Leuven : Peeters, 2018, p. 81-99

1 The contribution presents the ceramic findings from well 508 in Ville Royale I at Susa one of the five wells of the sector close to the Achaemenid city walls where deposits of Parthian Pottery where found. The archaeological investigations in the late 70 s aimed at establishing a solid relative chronology for the III millennium BC, therefore the later periods and the materials found in the wells did not get the attention they deserved at that time. Now the scholar who conducted those archaeological investigations analyses the Parthian period materials putting them in connection with similar objects and pottery sherds found elsewhere in Susa. The interesting element of the contribution consists in the publication of old materials in the light of later publications on Susa's Parthian pottery found after the wells' investigation. 


\section{AUTHORS}

\section{LEONARDO GREGORATTI}

Durham University 